\title{
Economics of Small Scale Capture Fishing in Dekhar Haor of Sunamganj District, Bangladesh
}

\author{
Muslima Akter* \\ Assistant Professor, Department of Agricultural Economics and Policy \\ Sylhet Agricultural University, Sulhet, 3100 \\ Prof. Dr. Jasim Uddin Ahmed \\ Department of Agricultural Economics and Policy \\ Sylhet Agricultural University, Sulhet, 3100 \\ Kanij Fatema \\ Associate Professor, Department of Agricultural Economics and Policy \\ Sylhet Agricultural University, Sulhet, 3100 \\ Tabia Binte Shan \\ Assistant Professor, Department of Agricultural Economics and Policy \\ Sylhet Agricultural University, Sulhet, 3100 \\ Tumpa Datta \\ Assistant Professor, Department of Agricultural Finance and Banking \\ Sylhet Agricultural University, Sulhet, 3100
}

\begin{abstract}
The research is financed Ministry of Science and Technology through the award of "National Science and Technology Fellowship 2017-18.

\section{Abstract}

This study was aimed at estimating profitability and identifies determinants of profit at the small scale farm level of fishing community in some areas of Dekhar haor under Sunamganj district. Data were collected through structured questionnaire from 100 fishermen by using random sampling. Descriptive statistics was used to estimate the cost and returns while linear regression model was used to estimate the determinants of the profitability. The results showed that per season gross return and net profit were Tk. 79178.40 and Tk. 58833.64 respectively for small scale haor fishing. Results from regression shows that, among the variables profitability was affected by experience, net cost, boat ownership status, food cost and maintenance and miscellaneous cost.
\end{abstract}

Keywords: Profitability, determinants, haor, Bangladesh.

DOI: $10.7176 / \mathrm{JBAH} / 11-23-01$

Publication date: December $31^{\text {st }} 2021$

\section{Introduction}

Bangladesh is a tropical and most densely populated country which is located in the northeastern part of southern Asia. The country has the widest spectrum of inland water resources comprising floodplains, natural depressions, rivers, reservoirs, ponds, coastal and marine water bodies. Among them floodplains/wetlands are most important geographical features for Bangladesh. Graced by numerous floodplain and coastal water bodies, fishery in Bangladesh plays a very significant role in terms of nutrition, employment, foreign exchange earnings and food supply.

Fish supplements about $60 \%$ of Bangladeshi people's daily animal protein intake (DoF, 2016). The fisheries can broadly be classified into three categories: inland capture fisheries, inland aquaculture and marine fisheries (DoF, 2016).

Total fish production of the country is around 42,76,641 MT of which inland culture fisheries, inland capture fisheries and marine capture fisheries contribute about 56.25\%, 28.45\% and 15.30\% respectively (DoF, 2018). Inland capture fisheries consist of marshy wetlands which are named as haor. It is a marshy wetland ecosystem which physically is a bowl or saucer shaped depression that looks like inland seas during the monsoon floods (Hasan et al., 2017). Haors are found mainly in the north eastern region of Bangladesh which is covering the parts of greater Sylhet and Mymensingh. In Sylhet district most important haors are Hakaluki haor, Dekhar haor, Saneer Haor, Tanguar haor, Hail Haor, Maker haor, Chayer haor and Kawadighi haor (Hossain, 2014). Among them, Dekhar haor is a resourceful wetland basin located in Sunmaganj district. The haor is composed of 36 small and large interconnecting beels, channels, rivers and crop lands and covers about 11514.6 hectares (CNRS, 2004). It is an important habitat for freshwater fish production, meeting local and national demand for fish protein and serve as a good source of fish seed supply for other 
nearby water bodies. It also provides suitable areas for feeding, breeding, nursing and so on for thousands of indigenous fish. This qualities leads to high yield and leads to substantial increase in fish production. A large number of populations of the area depend upon catching fish from the haor open water body. So, it is necessary to analyze the economic performance of fish catching and identify the factors that influencing profitability in the study area. Therefore, this study was undertaken to achieve the following objectives:

i) To determine profitability of small scale capture fishing in Dekhar haor

ii) To identify the factors affecting profitability in the study area

\section{Methods and materials}

For this study the area selected was Dekhar Haor which is under Dakshin Sunamganj Upazila of Sunamganj district. The data were collected from three villages of Dakshin Sunamganj Upazila: Noagaon, Kaikkar par and Rabbanigor. Primary data were collected through simple random sampling. Both part time and full time fishermen were considered for the study. Data was collected during the period from 2018-2019 from 100 fishermen.

\section{Analytical Technique}

Data were analyzed with the combination of tabular and functional analysis to fulfill the objectives. Descriptive statistics, inferential statistics and econometric analysis were applied to analyze the data collected from fishermen. In this study the following techniques were used:

\subsection{Descriptive Statistics}

Descriptive Statistics was used to get the simple measures like average, percentage and ratio. The calculation procedure of the entire technique was based on weighted average to describe input use, cost and returns of the small scale haor fishermen.

\subsubsection{Profitability of small scale fishing}

Cost and returns analysis is the most common method for determining and comparing profitability of any enterprise. Profit, also called net return, is the difference between total return and total cost. The following equation was used to determine the fishermen profitability at small scale level (Dillon and Hardaker, 1993):

$$
\pi=\sum_{i=1}^{n}\left(P_{Y_{i}} \cdot Y_{i}\right)-\sum_{i=1}^{n}\left(P_{X_{i}} \cdot X_{i}\right)-T F C .
$$

Where,

$\pi=$ Profit,

$P_{Y_{i}}=$ Price per unit of the i-th produces;

$Y_{i}=$ Quantity of the i-th produces;

$P_{X_{i}}=$ Price per unit of the i-th input;

$X_{i}=$ Quantity of i-th input;

TFC $=$ Total fixed cost; and

$\mathrm{i}=1,2,3$ $\mathrm{n}$ (number of times)

\subsubsection{Specification of empirical model}

Regression analysis was used to identify the relationship between dependent variable which is net return at farm level and cost of inputs used to catch fish in the haor area as independent variables. The regression model can be written as:

Where,

$$
Y_{i}=f\left(X_{i}\right)
$$

$Y_{i}=$ Profit at the farm level;

$X_{i}=$ Factors influencing the level of profit of fish catching.

The model could be written in explicit form as;

$Y_{i}=\beta_{0}+\beta_{1} X_{1}+\beta_{2} X_{2}+\beta_{3} X_{3}+\beta_{4} X_{4}+\beta_{5} X_{5}+\beta_{6} X_{6}+\beta_{7} X_{7}+\beta_{8} X_{8}+\beta_{9} X_{9}+u_{i}$

Where,

$Y_{i}=$ Amount of profit realized by fish farmer (Tk.)

$\beta_{0} \ldots \ldots \ldots \beta_{9}=$ Parameters

$\boldsymbol{X}_{1}=$ Age of the respondent (Years)

$\boldsymbol{X}_{2}=$ Experience in fish catching ( Years)

$\boldsymbol{X}_{6}=$ Boat ownership status, $1=$ Yes, $0=$ otherwise

$\boldsymbol{X}_{3}=$ Main occupation of the Respondent( $1=$ Fishing, $0=$

Otherwise)

$\boldsymbol{X}_{4}=$ Family size (No.)

$X_{7}=$ Bait cost (Tk.)

$\boldsymbol{X}_{5}=$ Net cost (Tk.)

$X_{8}=$ Food cost (Tk.)

$u_{i}=$ Error term

$X_{9}=$ Maintenance and miscellaneous cost (Tk.) 


\section{Results and discussion}

\subsection{Estimation of cost and returns associated with fish catch}

In the study area fishermen catch fish six month in a year. So cost and returns were calculated for six month.

\subsubsection{Total variable cost}

From the study it was observed that, total variable cost of fish catching per season was BDT $15915.58 \mathrm{Tk}$. The highest portion of the total variable cost was contributed by cost of net which was about $66.23 \%$ of the total variable cost. This is followed by food cost of fishermen during fishing representing $18.49 \%$. Food cost is those cost which was spent during fishing time for the fishermen. Maintenance and miscellaneous cost was $9.29 \%$ of the total variable cost. Bait was used as food on a hook to catch fish. The remaining group of variable cost which constitutes bait cost and interest on operating capital was $5.99 \%$.

Source: Field survey, 2019

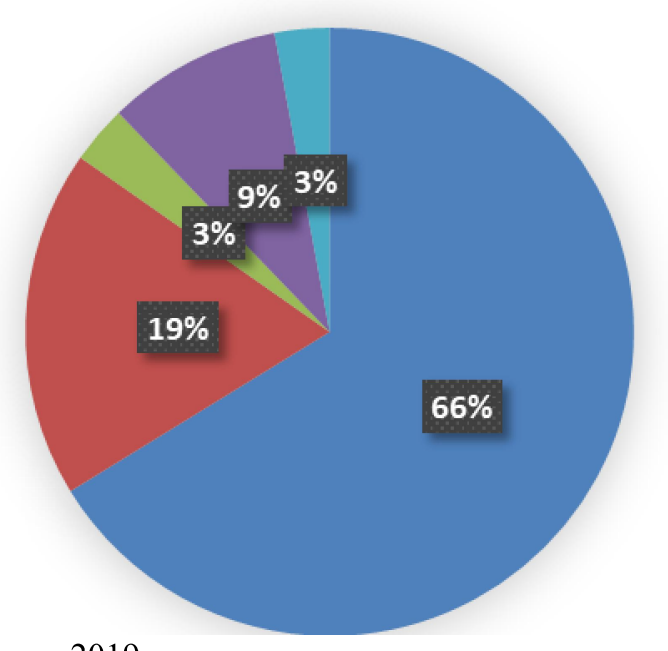

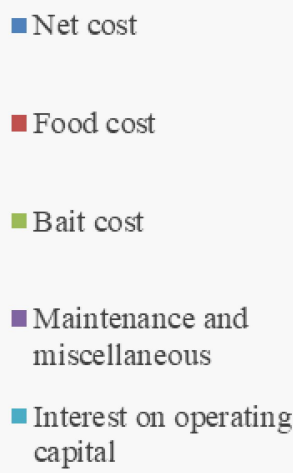

\section{Figure 1. Variable cost incurred by fishermen for six months}

\subsubsection{Total fixed cost}

Total fixed cost per season for the fishermen of haor fish catching was BDT Tk. 4429.18 of which boat cost constitutes about $50.33 \%$ and lease cost of the beels $49.57 \%$ of the total cost respectively.

Table 1 . Fixed cost incurred by fishermen for six months

\begin{tabular}{|l|l|l|}
\hline Item & Taka/ Season & $\%$ of total \\
\hline Boat cost ( Depreciation) & 2229.18 & $50.33 \%$ \\
\hline Lease value & 2200.00 & $49.57 \%$ \\
\hline Total & & $100 \%$ \\
\hline
\end{tabular}

4.1.3 Total cost

Total cost was calculated by summing up total variable cost and total fixed cost incurred by fishermen. Per season total cost of fish catching of the study area was BDT Tk.20344.76.

\subsubsection{Economic returns of the fish catching per season}

A large variety of known and unknown species were caught by fishermen. For profitability calculation small, medium and large size of small indigenous fish species were considered. The amount of fish catching depends on types of net used and the number of hours spent at haor. Table 2 shows that highest amount of fish catch by fishermen was puti which was $16.54 \mathrm{~kg} /$ month and the lowest amount was baim which was $5.59 \mathrm{~kg} / \mathrm{month}$. This result is found consistent with the findings of Muzahid et al 2017.

\subsubsection{Gross return}

Gross return consisting of revenue from fishing was calculated by multiplying the total catch by their respective prices. The highest amount of gross return was for escha and that was $3148.64 \mathrm{Tk} / \mathrm{month}$ and the lowest one for taki which was $923.79 \mathrm{Tk} /$ month. In the study area per month average gross return from all species was found Tk. 13196.89 and per season it was Tk. 79178.40 respectively.

\subsubsection{Net return and profitability of fish catching per season}

Net return is the difference between gross return and total cost. Table 2 presents per season gross return, total cost and net return of fish catching. Per season net return earned by fishermen were Tk. 58833.64 under different fishing gears (Table 2). 
Table 2: Economic returns of the hoar fish catching per season

\begin{tabular}{|l|l|l|l|l|}
\hline Sl. No. & Name of the fish species & $\begin{array}{l}\text { Quantity } \\
(\mathbf{K g})\end{array}$ & $\begin{array}{l}\text { Price } \\
\text { (Tk./Kg) }\end{array}$ & Total Return \\
\hline 1 & Puti (Putius ticto) & 16.54 & 102.04 & 1687.74 \\
\hline 2 & Tengra (Mystus vittatus) & 11.13 & 246.55 & 2744.10 \\
\hline 3 & Baim (Macrognathus aral) & 5.59 & 246.20 & 1376.25 \\
\hline 4 & Chela (Chela bacaila) & 6.84 & 166.60 & 1139.54 \\
\hline 5 & Veda (Nundus nundus) & 8.49 & 256.40 & 2176.83 \\
\hline 6 & Taki (Channa punctate) & 11.13 & 83.00 & 923.79 \\
\hline 7 & Escha (Macrobrachium indella) & 13.37 & 235.50 & 3148.64 \\
\hline Gross return per month & - & 73.09 & 180.55 & 13196.89 \\
\hline Gross return per Season & - & 438.09 & 180.55 & 79178.40 \\
\hline Total cost (TVC+TFC) & - & - & - & 20344.76 \\
\hline Net return & - & - & - & 58833.64 \\
\hline
\end{tabular}

Source: Field survey, 2019

\subsection{Factors affecting profitability at small scale farm level}

The results of the regression model are presented in Table 3. The estimated measure of goodness of fit (R-square) which is value of 0.728 implies that about $72.8 \%$ of variations in the profitability of small scale fish farming are explained by the specified explanatory variables in the model. In case of the explanatory variables, the model revealed that five of the nine hypothesized variables were statistically significant at $p<0.05$ level.

Table 3: Factors affecting profitability at small scale farm level

\begin{tabular}{lllll}
\hline Variables & Coefficient & Std Error & t-value & Level of significance \\
\hline Intercept & 8925.320 & 4739.903 & 1.883 & 0.063 \\
Age of the fishermen & -120.406 & 77.503 & -1.554 & 0.124 \\
Experience in fish catching & $1536.035^{* *}$ & 197.006 & 7.797 & 0.000 \\
Main occupation of the Respondent & -2253.455 & 1629.254 & -1.383 & 0.170 \\
Family size & 142.416 & 255.170 & 0.558 & 0.578 \\
Net cost & $-0.329^{* *}$ & 0.087 & -3.775 & 0.000 \\
Boat ownership status & $5151.541^{*}$ & 1433.975 & 3.592 & 0.001 \\
Bait cost & -5.212 & 5.426 & -0.960 & 0.339 \\
Food cost & $-0.759^{*}$ & 0.339 & -2.242 & 0.027 \\
Maintenance and miscellaneous & $-1.532^{*}$ & 0.669 & -2.291 & 0.024 \\
cost & & & &
\end{tabular}

Here, ${ }^{* *}$ Significant at $1 \%$ level; $*$ Significant at 5\% level. R Square $=0.728$; Adjusted R Square $=0.701$. Source: Authors' computation, 2019

From the Table 3, it was observed that the years of experience in fish catching was significant with a positive coefficient, implying that the profit level increases as the fishermen's experience increases. This result is in line with other studies of Ugwumba and Chukwuji, (2010); Pius and Victor (2014). They also found that the effect of farming experience on profitability is positive and an increase in the experience leads to an increased output of fish by the fisherman. The cost variables (e.g. net cost, food cost, maintenance and miscellaneous cost) had negative and significant effect on profitability at small scale fish farming. The negative effect of different variable cost items implies that, increasing variable costs exerts downward pressure on expected farm profitability in the study area. The result is consistent with other studies which reveal that different costs has a direct relationship to fish output in small scale farming, indicating that more the cost, lower the profit. (Hyuha et. al. 2011; Olukunle 2017). In contrast, the effect of boat ownership is measured through a dummy variable and the estimated coefficient has the hypothesized positive effect. This can be due to the fact that, own boat of fisherman can help him to provide control over the renting and transportation cost. Apart from that, he had not to depend on others in case of scheduling his fishing time and length.

\section{Conclusion}

Capture fishing is profitable in the study area. It is a major source of income for most of the people of the haor area. It helps to create employment opportunity which also helps to improve their socio-economic conditions. Profitability of fish catching is positively influenced by years of experience in the fish catching and negatively influenced by most variable cost items such as net cost, bait cost and maintenance and miscellaneous cost. That means if cost increased profitability will be reduced. Findings suggest that agricultural policy should give emphasis on access of small scale haor fishermen to adequate inputs at reduced cost so that profitability can be increased. 


\section{References}

CNRS. (2004). Center for Natural Resource Studies. Management of aquatic ecosystems through community husbandry. Feasibility report on MACH (Management of Aquatic Ecosystems through Community Husbandry) outreach program. 10pp.

Dillon, J. L., \& Hardaker, J. B. (1993). Farm Management Research for Small Farmer Development, FAO Publication, Rome, Italy.

DoF. (2016). Department of Fisheries, Ministry of Fisheries and Livestock, Government of the people's Republic of Bangladesh, Dhaka.

DoF. (2018). Department of Fisheries, Ministry of Fisheries and Livestock, Government of the people's Republic of Bangladesh, Dhaka.

Hasan, M., Safikul, H., \& Simul, B. (2017). Fish Diversity Assessment of the Haor Region in Kishoreganj District, Bangladesh. Research Journal of Environmental Science, 1, 29-35. https://scialert.net/abstract/?doi=rjes.2017.29.35

Hossain, M. A. R. (2014). An overview of fisheries sector of Bangladesh, Res. Agric. Livest. Fish. 1, 109-126. DOI:10.3329/ralf.v1i1.22375

Hyuha, T. S., Bukenya, J. O., Twinamasiko, J., \& Molnar. J. (2011). Profitability analysis of small scale aquaculture enterprises in Central Uganda. International Journal of Fisheries and Aquaculture, 15, 271-278. DOI: $10.5897 /$ IJFA11.069

Ike, P. C., \& Okonta, V. A. C. (2014). Determinants of Output and Profitability of Aquaculture Fish Farming in Burutu and Warri South West Local Government Areas of Delta State, Nigeria. Journal of Biology, Agriculture and Healthcare, 4, 102-108.

Mozahid, M. N., Ahmed, J. U., Mannaf, M., Akter, S., \& Alam. M. S. (2017). Fish Biodiversity and Economic Performance of Fish Catching in Dekhar Haor: A Case Study of Sunamganj District, Bangladesh. IOSR Journal of Economics and Finance, 5, 66-72. DOI:10.9790/5933-0805026672

Olukunle, O. T. ( 2017). Profitability Analysis of Small Scale Fishery Enterprise in Nigeria. Journal of Agricultural Science, 3, 107-116. DOI:10.5539/jas.v9n3p107

Ugwumba, C. O. A., \& Chukwuji C. (2010). The economics of catfish production in Anambra state. Nigeria, Journal of Agriculture and Social Sciences, 4, 105- 109. DOI:10.22161/ijeab/1.3.2 